\title{
RISALAH|
}

DOI: $10.24014 /$ jdr.v31i1.9838

\section{STRATEGI KOMUNIKASI TAKMIR DALAM MEMAKMURKAN MASJID JOGOKARIYAN YOGYAKARTA}

\author{
Atik Nurfatmawati \\ Sekolah Tinggi Agama Islam Mulia Astuti (STAIMAS) Wonogiri \\ Email: atikstaimas@gmail.com
}

\section{Kata kunci}

Strategi Komunikasi, Takmir, Masjid.

Keywords

Communication

Strategy,

Takmir, Mosque

\begin{abstract}
Abstrak
Masjid megah belum tentu diimbangi semangat memakmurkan masjid. Hal ini berbeda dengan Masjid Jogokariyan di Yogyakarta, selain untuk salat berjamaah juga menjadi pusat kegiatan sosial kemasyarakatan. Tujuan penelitian ini adalah untuk menganalisis strategi komunikasi takmir dalam upaya memakmurkan Masjid Jogokariyan. Penelitian ini menggunakan teori komunikasi antarpribadi dengan pendekatan kualitatif deskriptif. Informan penelitian ini empat orang taknir Masjid Jogokariyan. Hasil penelitian ini yaitu strategi pendekatan personal menjadi salah satu kunci keberhasilan membangun proses komunikasi. Komunikasi takmir masjid dengan masyarakat sekitar, jamaah, dan pengunjung masjid dilakukan secara persuasif. Takmir masjid juga sering mengadakan kegiatan sosial bersama masyarakat, baik muslim maupun non muslim. Upaya memakmurkan masjid dilakukan melalui pendekatan personal, melalui hobi yang disukai warga yang belum salat. Selain itu, takmir masjid berupaya menjaga kenyamanan para tamu baik yang beribadah atau sekadar singgah.
\end{abstract}

\begin{abstract}
The magnificent mosque is not necessarily offset the spirit of the prosperity of the mosque. This is different from the Jogokariyan Mosque in Yogyakarta, in addition to congregational prayers it is also a center of social activities. The purpose of this study was to analyze the takmir communication strategy to prosper the Jogokariyan Mosque. This study uses interpersonal communication theory with a descriptive qualitative approach. The informants of this study were four people from the Jogokariyan Mosque. The results of this study are the personal approach strategy is one of the keys to success in building the communication process. Mosque takmir communication with the surrounding community, worshipers, and mosque visitors is carried out persuasively. Takmir Masjid also often holds social activities with the community, both Muslim and nonMuslim. Efforts to make the mosque prosperous through a personal approach, through hobbies that are favored by residents who have not yet prayed. Besides, the mosque takmir seeks to maintain the comfort of guests whether worshiping or just stopping by
\end{abstract}




\section{Pendahuluan}

Umumnya masjid hanya digunakan untuk aktivitas ibadah salat dan kegiatan pengajian. Masjid ramai hanya pada saat bulan suci Ramadhan. Di sinilah diperlukan strategi atau upaya takmir dalam memakmurkan masjid. Salah satu masjid di Indonesia menjadi percontohan dalam hal kemakmuran adalah Masjid Jogokariyan. Masjid Jogokariyan merindukan suasana masjid seperti zaman Rasulullah Shallallahu'alaihi Wasallam. Sapri et al. (2016) menyebutkan bahwa fungsi masjid menjadi berkurang. Seiring perubahan waktu, fungsi masjid menjadi sempit dan hanya dikenal sebagai tempat beribadah di kalangan generasi sekarang. Hasil penelitiannya di Malaysia menjelaskan, pemerintah setempat menghabiskan miliaran ringgit untuk membangun sebuah masjid yang bagus dalam desain arsitektur. Tapi jumlah jamaah internal dan eksternal yang datang ke masjid justru semakin menurun.

Indikator kemakmuran tidak terletak pada megah dan luasnya bangunan. Makmurnya masjid dapat dilihat dan dirasakan pada aktivitas masjid yang mampu memahami kebutuhan warga setempat, sehingga aktivitas warga berpusat di masjid. Lazim jika Masjid memiliki sarana dan prasarana pendukung bagi kenyamanan jamaah. Saat ini Masjid Jogokariyan sebagai institusi percontohan mampu menarik minat masyarakat setempat turut serta mengelola masjid. Pelayanan diberikan dalam kegiatan ibadah, pendidikan, sosial, kesehatan, kesenian dan olah raga. Hal ini bertujuan mendekatkan serta menciptakan ikatan sesama warga. Sinambela (2010) mengungkapkan pada dasarnya setiap manusia membutuhkan pelayanan, bahkan secara ekstrim dapat dikatakan bahwa pelayanan tidak dapat dipisahkan dengan kehidupan manusia. Ketika masa kecil anak-anak belajar dan bermain di masjid maka ketika dewasa akan turut serta menjadi donatur Masjid Jogokariyan. Takmir menyadari bahwa anak-anak inilah masa depan generasi penerus masjid. Apapun aktivitasnya selalu untuk mendekatkan anak-anak ke masjid. Masjid ini juga menerapkan saldo infak 0 (nol) persen, sehingga jumlah infak selalu tersalurkan. Masjid Jogokariyan pada 14 Januari 2017 lalu, mengadakan tasyakuran mengundang 1.000 jamaah.

Menurut Islamic Religious Council of Singapore (MUIS, 2005), faktor penting yang berkontribusi dalam kesejahteraan masjid adalah manusia. Mereka mengatakan, dua kelompok orang akan menentukan makmur tidaknya sebuah masjid adalah pengelola atau pekerja masjid, dan jamaah (kongregasi masjid). Hal ini menunjukkan bahwa faktor manusia berperan penting untuk mempertahankan masjid dalam jangka panjang. Dari perspektif bisnis, kelompok orang bisa dianggap sebagai pelanggan terpenting masjid. Penting memberikan layanan guna memenuhi kebutuhan dan harapan pelanggan (jamaah). Agar masjid dapat tampil dengan inspirasi mengangkat dan mempertahankan fungsinya sebagai pusat komunitas, harus memperhitungkan layanan yang memenuhi kebutuhan dan harapan masyarakat (Sapri, 2010).

Dewan Kemakmuran Masjid (DKM) biasa dikenal dengan sebutan takmir masjid. Kata takmir diambil dari kata 'ammara-yu'ammiru-ta'miirun, artinya "memberi umur". Memberi umur dapat diterjemahkan dengan memakmurkan. Di Indonesia 
pengurus masjid lebih dikenal dengan takmir masjid, meski demikian istilah DKM juga dipakai di beberapa masjid. Takmir memiliki susunan kepengurusan sesuai dengan fungsi dan tanggung jawab masing-masing pengurus. Terdapat ketua, bendahara, imam, khatib, muazin dan beberapa jabatan kepengurusan lainnya. Mengelola masjid tentu bukan perkara mudah, diperlukan upaya dan program-program.

Pada masa Rasulullah masjid menjadi pusat kegiatan seluruh aktivitas umat. Memakmurkan masjid bukan perkara mudah, betapa banyak bangunan masjid yang megah, indah serta luas, tetapi hanya memiliki saf sedikit. Tantangan utama dalam mengelola masjid saat ini adalah memastikan praktik pengelolaan yang efisien dan tepat (Adil et al., 2013). Para imam biasanya orang yang sangat dihormati di antara kaum muslim (Rogers, 1975; Wall \& Callister, 1999) dan berfungsi di institusi masjid (Mokhtar, 2003; Mohammad, 2008). Kitab suci Alquran menyebutkan kata imam dua belas kali, menunjukkan arti imam adalah pemimpin rakyat (Zaki, 2007). Peran imam dalam aspek pengelolaan kehidupan manusia (hirasah ad-dunya) dan juga mengelola agama Islam (hirasah ad-din) (Zaki, 2007). Kata imam dalam sastra Islam berarti seseorang yang bertanggung jawab memimpin orang lain baik aspek fisik maupun agama. Hal ini menunjukkan bahwa dalam peradaban Islam, imam adalah posisi tertinggi yang bisa diberikan kepada seseorang di negara Islam. Kata imam di literatur Islam mengandung makna sama dengan khalifah, malik, atau sultan, dan sebagainya, istilah tersebut membawa definisi pemimpin tertinggi dalam peradaban Islam (Zaki, 2007). Masjid adalah organisasi berbasis masyarakat (Mahaza, 2013). Peran serta masyarakat setempat selaku pengurus masjid sangat diperlukan. Ada nilainilai ibadah berlandaskan iman dan takwa kepada Allah sehingga secara suka rela menjadi takmir masjid atau pengurus masjid.

Remaja juga memiliki peran relatif besar dalam memakmurkan masjid. Dengan adanya remaja masjid yang aktif, maka regenerasi masjid dapat dilakukan. Semua elemen masyarakat baik tua, muda, anak-anak, maupun remaja, laki-laki dan perempuan, lajang atau sudah menikah, memiliki peran masing-masing dalam menjaga kemakmuran masjid. Bagi perempuan banyak aktivitas dapat dilakukan di masjid yang seperti menyiram tanaman, menyapu sampah, mengatur meja kursi, serta membersihkan area tempat ibadah (Ghani, 2013). Perempuan tidak hanya tinggal di rumah tetapi juga membutuhkan komunitas guna berinteraksi dengan tetangga.

Nabi Muhammad juga mengizinkan wanita mengikuti kelas pendidikan di masjid (Azhar, 2008). Kelas di masjid bagi wanita dapat disesuaikan dengan kebutuhan seperti menjahit, kelas Alquran, dan pembelajaran lainnya (Jaafar et al., 2013). Kontribusi keterlibatan warga sebagai jamaah sholat memiliki faktor dominan dalam organisasi kemasyarakatan. Menjaga kesejahteraan antarmuslim merupakan sebuah tuntutan dalam agama Islam. Tinggal di komunitas adalah sifat alami manusia. Manusia tidak bisa hidup sendiri tanpa bergaul dengan masyarakat atau tetangga. Islam mempromosikan saling menyapa dan mengencangkan ikatan, terlepas dari apapun 
agamanya (Jaafar et al., 2013). Wells \& Spinks (1999) menemukan bahwa komunikasi antaranggota komunitas sangat penting dalam sebuah organisasi.

Sapri (2016) menjelaskam, kata masjid adalah konversi kata Arab 'masjid' (jamak: masajid). Sujud merupakan tindakan paling terhormat dalam doa sebagai bentuk ketaatan kepada Allah. Dari literatur Islam, Nabi Muhammad tercatat dalam sebuah hadits Imam Bukhari menyatakan bahwa "Seluruh bumi dijadikan tempat ibadah". Jadi, dalam kerangka hukum Islam, seorang muslim bisa berdoa hampir di mana saja. Namun, tujuan utama pembangunan masjid adalah memfasilitasi ibadah ritual kolektif dalam bentuk shalat jamaah sehari-hari. Tanpa aktivitas ibadah, masjid menjadi bangunan umum.

Pihak berwenang di negara-negara non-muslim sepenuhnya menyadari peran masjid dalam memperkuat keterikatan pada nilai dan moral yang baik, berkontribusi mengurangi tingkat kejahatan dan kenakalan. Di negara-negara non-muslim, masjid bukan hanya tempat ibadah melainkan pusat akademik di mana konferensi diberikan oleh kaum intelektual atau warga asing. Beberapa masjid dikelola sedemikian rupa, memperkaya dan mengaktifkan aksi budaya Islam di luar dunia Islam (Saniei, 2012). Masjid merupakan salah satu sarana publik, di beberapa daerah atau negara masjid dijadikan ikon atau ciri khas. Beberapa contoh Masjid Istiqlal di Jakarta, Masjid Baitturrahman di Aceh, dan Blue Mosque di Turki.

Beberapa penelitian sebelumnya menemukan berbagai dinamika dalam memakmurkan masjid. Saputra \& Kusuma (2017) menjelaskan bahwa revitalisasi masjid berdampak pada beberapa aspek di antaranya aspek sosial, pendidikan, dan ekonomi. Aspek sosial kemasyarakatan yaitu tersedianya pelayanan kesehatan yang murah, rehabilitasi difabel, sampai kebutuhan feminis seperti ruang laktasi. Pada aspek pendidikan, masjid mengadakan kajian rutin dan penyediaan perpustakaan guna menambah wawasan dan literasi umat. Pada aspek pembangunan ekonomi umat, masjid berhasil meningkatkan kesejahteraan, meliputi pedagang, buruh gendong, pengayuh becak serta memberi beasiswa untuk anak-anak kurang mampu.

Penelitian Yosepin \& Husin (2018) menunjukkan bahwa Lembaga Takmir Masjid Nahdlatul Ulama (LTM NU) memiliki program revitalisasi dalam memaksimalisasi fungsi masjid yang berkelanjutan. LTM NU berhasil melakukan aktivitas dakwah kepada komunitas pengemudi di Jakarta Pusat, melalui komunikasi dakwah persuasif yang menciptakan civilization dakwah. Ibda \& Saifuddih (2019) menjelaskan LTM NU Temanggung memiliki strategi dalam mencegah radikalisme agama melalui penguatan manajemen takmir yang mengacu pada nilai-nilai Islam Aswaja An-Nahdliyah (Ibda \& Saifuddih, 2019).

Susanto (2015) menyampaikan penguatan manajemen masjid melalui beberapa pelatihan guna meningkatkan wawasan keislaman, melakukan pembaharuan pengurusan takmir, mengadakan rapat/ pertemuan/ musyawarah, dan pelatihan manajemen masjid. Arifah \& Zulfa (2018) menyimpulkan takmir memiliki peran idarah, imarah dan ri'ayah; merencanakan program kerja secara kompeten, mengatur pendidikan dan 
pengajaran Islam; mengatur dakwah; mengadakan kegiatan sosial; dan meningkatkan kesejahteraan dengan melengkapi fasilitas dan infrastruktur masjid.

Dari berbagai penelitian itu, belum ditemukan penelitian terkait strategi komunikasi takmir dalam upaya memakmurkan masjid. Untuk itu peneliti akan mengkaji strategi komunikasi takmir atas keprihatinan yang muncul, karena banyak masjid hanya difungsikan untuk ibadah salat saja. Berbeda dengan Masjid Jogokariyan Yogyakarta yang menjadi pusat kegiatan bermasyarakat dan memberikan solusi permasalahan sosial. Penelitian ini bertujuan menganalisis strategi komunikasi takmir dalam upaya memakmurkan Masjid Jogokariyan.

Peneliti akan menganalisis strategi komunikasi takmir dalam upaya memakmurkan masjid melalui perspektif teori komunikasi antar pribadi. Komunikasi antar pribadi adalah komunikasi antarperorangan dan bersifat pribadi, baik secara langsung ataupun tidak langsung. Kegiatan-kegiatan seperti percakapan tatap muka, melalui telepon, surat-menyurat (Sendjaja, 1994). Komunikasi antar pribadi merupakan proses komunikasi yang berlangsung antara dua orang atau lebih secara tatap muka seperti yang disampaikan R.Wayne Pace bahwa "Interpersonal communication is communication involving two or more people in face to face setting" (Cangara, 2014).

\section{Metode}

Penelitian ini menggunakan metode pendekatan kualitatif deskriptif. Pendekatan kualitatif adalah suatu proses penelitian dan pemahaman yang berdasarkan pada metodologi yang menyelidiki suatu fenomena sosial dan masalah manusia. Pada pendekatan ini, peneliti membuat suatu gambaran kompleks, meneliti kata-kata, laporan terperinci dari pandangan responden, dan melakukan studi pada situasi yang alami (Creswell, 2007). Sementara Bogdan \& Taylor mengemukakan bahwa metodologi kualitatif merupakan prosedur penelitian yang menghasilkan data deskriptif berupa kata-kata tertulis maupun lisan dari orang-orang dan perilaku yang diamati (Utama \& Mahadewi, 2018). Penelitian ini menggunakan metode studi kasus, merupakan strategi yang lebih cocok untuk pertanyaan penelitian berkenaan dengan how atau why bila peneliti hanya memiliki sedikit peluang untuk mengontrol peristiwa-peristiwa yang akan diselidiki, dan bilamana fokus penelitiannya terletak pada fenomena kontemporer (masa kini) di dalam konteks kehidupan nyata (Yin, 1996). Kategori studi yang digunakan adalah single case, single level analysis. Teknik pengumpulan data yang digunakan adalah wawancara mendalam. Teknik wawancara ini tidak dilakukan secara ketat terstruktur, tertutup dan formal, tetapi lebih menekankan pada suasana akrab dengan mengajukan pertanyaan terbuka, lentur dan bersikap jujur dalam menyampaikan informasi sebenarnya. Penelitian dilakukan pada akhir 2018 sampai awal 2019. Informan penelitian ini adalah takmir Masjid Jogokariyan (Tabel 1). 
Tabel 1. Daftar Narasumber Penelitian

\begin{tabular}{lll}
\hline No & Nama & Pekerjaan \\
\hline 1 & H. Muhammad Jazir ASP & Ketua Dewan Syuro \\
2 & Ust. Syubban Rizali Noor, S.Ag & Ketua Bidang III \\
3 & H.M. Rizqi Rahim, S.T., M.Eng & Bendahara \\
4 & Ahmeda Aulia Nurseta & Remaja Masjid \\
\hline
\end{tabular}

Sumber: Hasil wawancara penelitian

Sebagai data penunjang peneliti juga melakukan pengambilan data sekunder yang bersumber dari arsip, website resmi Masjid Jogokariyan, ceramah di YouTube dengan narasumber pengurus Masjid Jogokariyan yang sedang melakukan pelatihan, seminar atau tausiah tentang manajemen dan pelayanan masjid. Analisis adalah suatu usaha untuk mengurai suatu masalah atau fokus kajian menjadi bagian-bagian (decomposition) sehingga susunan/ tatanan bentuk sesuatu yang diurai itu tampak dengan jelas dan karenanya bisa secara lebih terang ditangkap maknanya atau lebih jernih dimengerti duduk perkaranya (Satori \& Komariah, 2009).

\section{Hasil dan Pembahasan}

Pemberian nama Masjid Jogokariyan berdasarkan Sunnah Nabi, di mana pemberian nama masjid berdasarkan nama daerah atau nama kampung. Masjid Jogokariyan terletak di Kampung Jogokariyan dengan luas tanah $1.478 \mathrm{~m}^{2}$. Masjid Jogokariyan terbuka untuk umum maupun musafir yang hendak singgah atau sekadar membersihkan diri. Tersedia fasilitas penginapan berbayar seperti layaknya hotel bintang tiga maupun fasilitas gratis bagi musafir. Fasilitas gratis yang tersedia yaitu peralatan masak seadanya seperti kompor, mie instan dan air mineral. Fasilitas tersebut disediakan terpisah agar tidak mengganggu aktivitas ibadah.

Ada berbagai fasilitas pendukung yang memberi kenyamanan dan keamanan jamaah Masjid Jogokariyan. Di lingkungan masjid tersedia akses internet gratis ramah anak yang sudah terfilter. Dari segi kemanan terdapat CCTV (Closed-Circuit Television) di beberapa sudut masjid. Akses masjid juga dibuka 24 jam, masjid dilengkapi dispenser, akses toilet yang bersih, kamar mandi, serta terdapat angkringan tempat warga setempat biasa berinteraksi. Masjid Jogokariyan juga sering mengundang ustaz-ustaz dari luar Kampung Jogokariyan untuk menyampaikan kajian-kajian dakwah.

Masjid Jogokariyan ini memiliki visi "Terwujudnya masyarakat sejahtera lahir bathin yang diridhoi Allah melalui kegiatan kemasyarakatan yang berpusat di Masjid". Untuk mencapai tujuan tersebut, perlu strategi komunikasi penyampaian pesan dan mentransfer ide serta gagasan guna merangkul lapisan masyarakat.

\section{Strategi Komunikasi Takmir}

Ketua Dewan Syuro Masjid Jogokariyan H. Muhammad Jazir ASP (Ustaz Jazir) mengungkapkan bahwa strategi pendekatan personal menjadi salah satu kunci keberhasilan membangung proses komunikasi. Ust. Jazir mengetahui proses pendirian, 
pembangunan maupun perkembangan Masjid Jogokariyan. Ustaz kelahiran Yogyakarta, 28 Oktober 1962 tersebut, menjelaskan sejarah perjuangan pendirian masjid:

Kisah tentang kaum abangan dan basis PKI berada di Kampung Jogokariyan dan perjuangan berangkat ke masjid ketika itu tidak mudah (Wawancara dengan Ustaz Jazir).

Ustaz Jazir menjadi Ketua Umum Takmir Masjid Jogokariyan pada tahun 1999. Gagasan, ide, inovasi dan terobosan dilakukan demi mendekatkan Masjid Jogokariyan kepada masyarakat setempat. Berawal dari niat mengembalikan nilai-nilai Islam, kini masjid Jogokariyan menjadi pusat sosialisasi masyarakat. Bersilaturrahiim ke semua warga di Kampung Jogokariyan menjadi strategi pendekatan personal yang berhasil dilaksanakan. Dari, oleh, dan bagi masyarakat, adalah manfaat yang kini dirasakan.

Pendekatan personal terbukti meningkatkan jumlah partisipasi aktif warga Kampung Jogokariyan, dari 30 jamaah kini mencapai ratusan. Pengamatan peneliti di lokasi, Masjid Jogokariyan yang memiliki dua lantai bahkan tidak mampu menampung jamaah salat subuh. Ini membuktikan bahwa masyarakat setempat sudah menjadi bagian Masjid Jogokariyan. Untuk mencapai hal itu, takmir juga harus menyatu dengan masyarakat.

Takmir harus mengenal secara utuh nama-nama kepala keluarga (Wawancara dengan Ustaz Jazir).

Perjuangan memakmurkan masjid diawali dengan membuat peta dakwah guna mengidentifikasi warga muslim yang sudah aktif ke masjid, telah berkurban, menunaikan zakat, berangkat haji atau umrah. Selain itu juga memetakan warga yang belum aktif ke masjid, belum berkurban, belum berzakat maupun belum berhaji atau umrah. Sesuai dengan ajaran Nabi Muhamad, kesejahteraan umat harus terjaga, maka dari peta dakwah tersebut dapat diketahui warga yang membutuhkan dan warga yang berkelebihan.

Dari pemetaan dakwah Masjid Jogokariyan inilah akan diketahui siapa, beragama apa, sudah salat atau belum, kalau sudah salat apakah sudah berjamaah di masjid, kalau belum salat kendalanya apa, apakah memiliki kendala tidak bisa membaca bacaan salat atau memang belum mau salat. Apakah sudah berkurban atau belum, sudah berangkat haji, umrah atau belum, memiliki usaha apa, atau bekerja di mana dan sebagai apa. Kedekatan sosial ini menjadi modal sosial penting bagi takmir dan komunitas Masjid Jogokariyan.

Di sekitar Masjid Jogokariyan terdapat 180 kepala keluarga penerima kartu ATM beras, yang dapat digunakan untuk mengambil beras selama 24 jam. Jamaah juga turut memiliki poliklinik gratis yang memberi layanan kesehatan kepada sekitar 1.830 kepala keluarga. Pengurus RT dan RW di sekitar masjid diberikan fasilitas asuransi kesehatan yang dibayarkan premi bagi muslim dan non muslim. Kedekatan inilah yang kemudian mendorong rasa toleransi yang tinggi bagi warga setempat. Takmir Masjid Jogokariyan juga sering mengadakan kegiatan pengajian bersama. 


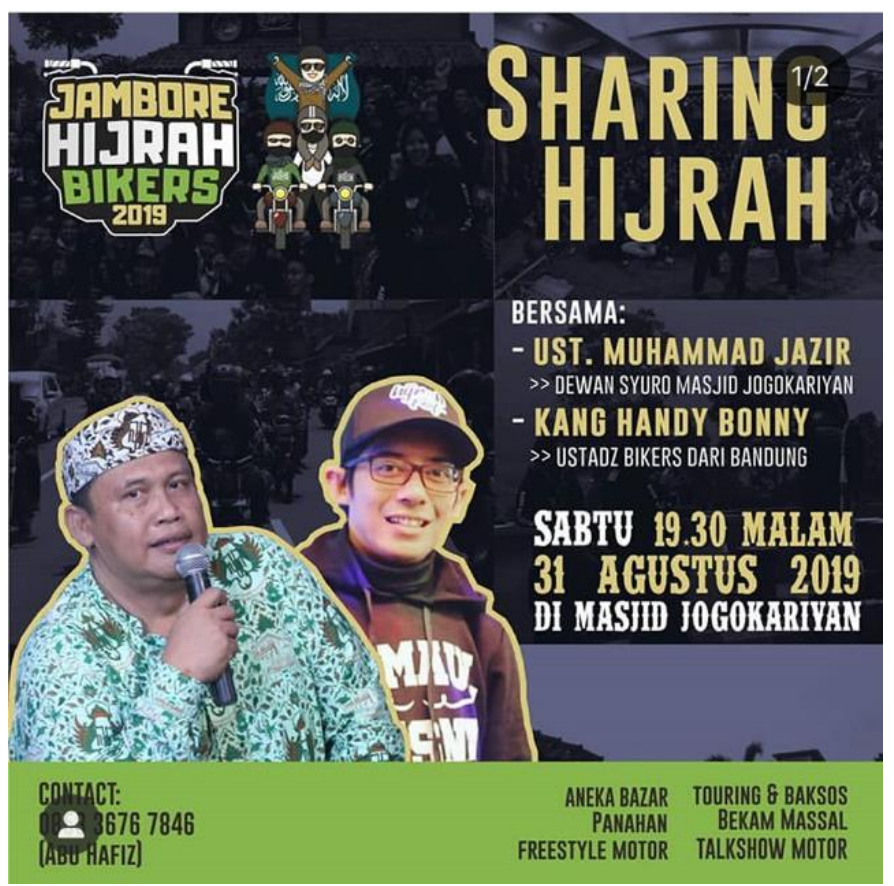

Gambar 1: Sharing Hijrah Ustaz Muhammad Jazir \& Kang Handy Bonny

(Sumber: Instagram @masjidjogokariyan)

Ustaz Syubban Rizali Noor selaku Ketua III Masjid Jogokariyan menguatkan pendapat bahwa yang dicapai Masjid Jogokariyan saat ini adalah buah perjuangan panjang. Masjid tersebut juga menjadi tepat bermain bagi anak-anak dan pihak takmir menyediakan jajanan kecil dan minuman demi kenyamanan anak-anak. Di masjid ini segala fasilitas disediakan, takmir memiliki kewajiban melayani jamaah anak-anak hingga orang tua.

Tidak ada anak kecil bermain di Masjid Jogokariyan yang akan dimarahi (Wawancara dengan Ustaz Syubban).

Anak-anak bahkan diberi fasilitas stick game, permainan karambol, memanah, dan pentas seni. Masjid Jogokariyan juga menyediakan Wifi gratis yang dapat diakses secara aman. Lampu masjid juga menyala terang jika malam hari. Lingkungan Masjid Jogokariyan yang berdampingan dengan area wisata membuat takmir melakukan inovasi dan terobosan demi menjaga akhlak, iman dan takwa anak-anak, remaja dan orang tua. Secara rutin ada berbagai lomba yang diadakan. Setiap bulan Ramadhan dalam kondisi normal, setiap hari Masjid Jogokariyan menyediakan 2.500 porsi piring makan untuk berbuka puasa. 


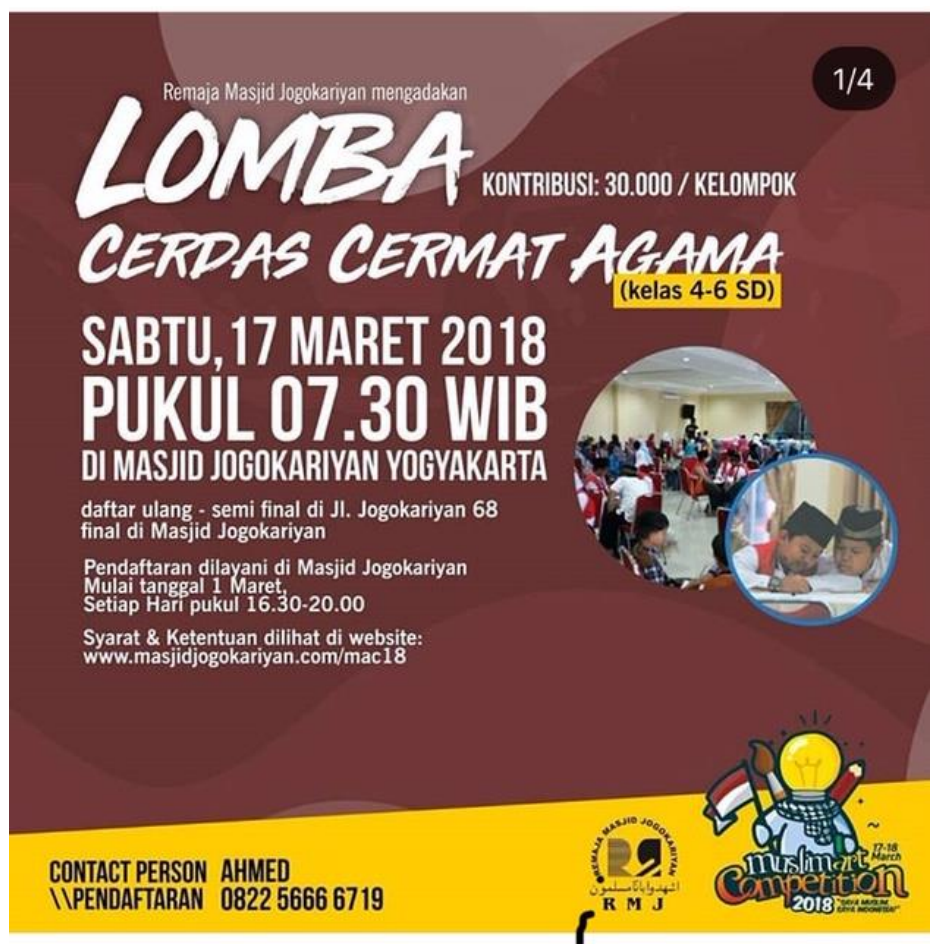

Gambar 2 : Salah satu lomba rutin yang diselenggarakan oleh remaja masjid

(Sumber: Instagram @masjidjogokariyan)

Informan lainnya, H.M. Rizqi Rahim selaku bendahara masjid, juga masuk dalam jajaran takmir, menjelaskan konsep infak nol rupiah. Maksudnya, semua uang yang masuk ke masjid langsung memiliki pos dan penyaluran, tidak ada saldo yang mengendap. Dana infak disalurkan untuk kebutuhan warga secara transparan untuk santunan kesehatan, perbaikan ekonomi dan pendidikan. Semua penggunaan dana secara akuntabel dan dapat dipertanggungjawabkan. Program-program sosial kemasyarakatkan yang dibuat mampu menumbuhkan rasa percaya menyalurkan zakat, infak dan sedekah di masjid. Institusi masjid bekerja sama dengan ketua RT/ RW (Rukun Tetangga/ Rukun Warga) mampu mengidentifikasi penyaluran zakat, infak dan sedekah. Masjid juga mandiri, tidak mengedarkan proposal bantuan ke mana pun.

Fasilitas bagi musafir disediakan ruangan untuk istirahat gratis dan disediakan kompor, mie instan, air mineral. Ruangan transit bagi musafir terbuka 24 jam, meskipun tak dapat dipungkiri masjid Jogokariyan memiliki tempat penginapan sekelas bintang tiga yang berbayar. Pengurus masjid tidak akan mengedarkan proposal ke rumah-rumah warga untuk membiayai operasional. Masjid diupayakan mandiri melalui unit usaha yang dimiliki (Wawancara dengan H.M. Rizqi Rahim).

Fasilitas lain yang diberikan adalah adanya angkringan bagi para pengunjung. Angkringan selalu penuh dan terlihat ramai. Pihak angkringan tidak perlu menyewa, pengurus masjid sengaja menyediakan lahan untuk berjualan bergiliran bagi warga demi memberdayakan warga Jogokariyan. Upaya lain, tim keamanan masjid akan 
memberikan ganti $100 \%$ bagi jamaah masjid yang melaporkan kehilangan barang. Tim keamanan masjid juga membantu jika ada pihak-pihak yang mengaku kehabisan bekal.

Tim keamanan wajib berprasangka baik apapun kondisinya. Pernah ada satu keluarga minta ongkos pulang ke daerah, maka tim keamanan akan mengantarkan ke terminal dan membelikan tiket untuk pulang. (Wawancara dengan H.M. Rizqi Rahim)

Setiap Rabu, setelah Isya ada tim kesehatan gratis atau klinik kesehatan masjid yang disediakan bagi warga Jogokariyan yang ingin memerikasakan kesehatan. Selain itu jika Ramadhan tiba, takmir menyediakan lebih dari 1.000 piring atau mangkok untuk buka puasa. Jumlah piring atau mangkok ini meningkat setiap tahun. Semarak warna warni akan terlihat di kampung Masjid Jogokariyan saat Bulan Suci Ramadhan tiba.

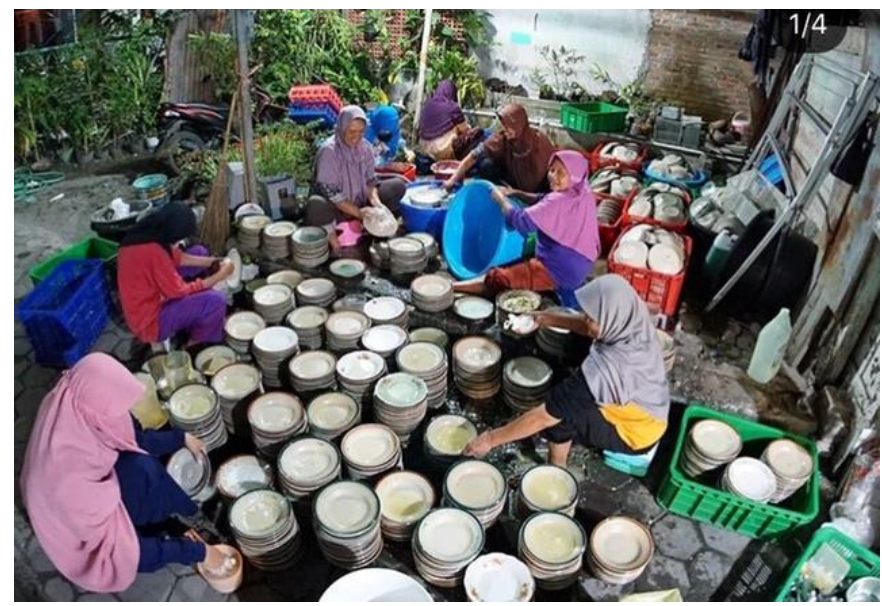

Gambar 3 : Ibu-ibu PKK dan remaja mencuci 2.500 piring saat Ramadhan 2018 (Sumber: Instagram @masjidjogokariyan)

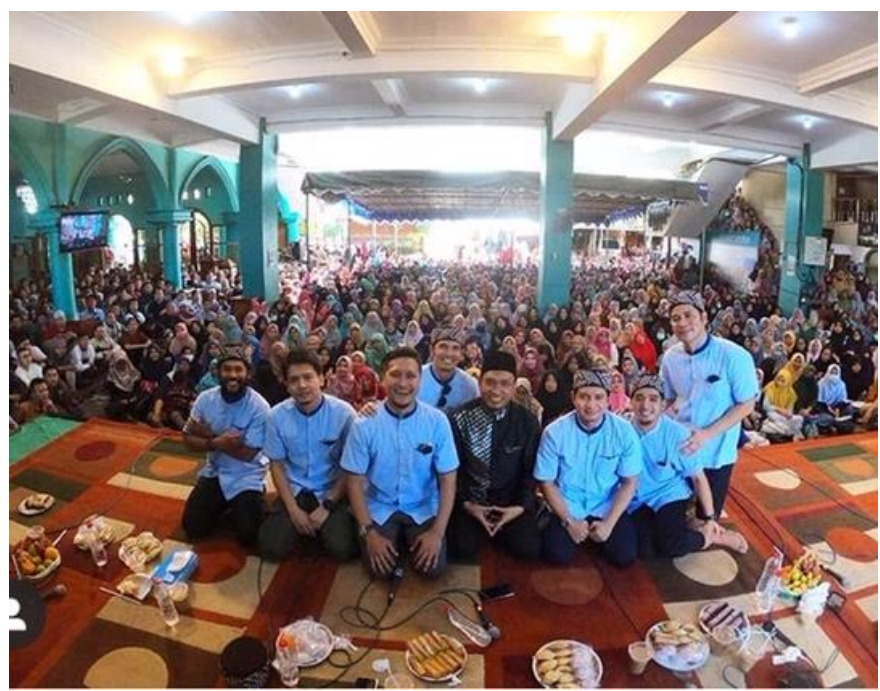

Gambar 4 : Artis-artis dari Jakarta Silaturahim di Masjid Jogokariyan (Mei, 2019) Sumber: Instagram @ masjidjogokariyan) 
Liliweri (2011) menyampaikan ciri-ciri komunikasi antarpribadi yang efektif dengan adanya keterbukaan, empati, dukungan, rasa positif dan kesetaraan. Takmir masjid sebagai komunikator antarpribadi yang efektif harus terbuka kepada komunikan, dalam hal ini adalah jamaah. Dalam teori komunikasi interpersonal fokus aktivitas yang dilakukan adalah melalui percakapan. Percakapan yang dilakukan takmir Masjid Jogokariyan melalui silaturahim yang intens kepada jamaah setempat. Hal ini berdampak baik pada antusiasme jamaah salat lima waktu di masjid dan keaktifan jamaah dalam berbagai kegiatan masjid.

\section{Upaya Memakmurkan Masjid Jogokariyan}

Kegiatan memakmurkan Masjid Jogokariyan dilakukan melalui pendekatan personal, misalnya melalui hobi yang disukai warga yang belum salat. Jika banyak warga yang memiliki hobi sepeda, maka takmir membentuk komunitas sepeda Jogokariyan. Ketika banyak warga yang memiliki kegemaran memancing maka takmir membentuk komunitas mancing mania. Hasil dari interaksi ini terjadinya kedekatan personal. Takmir juga memiliki prinsip, apapun aktivitas yang dikerjakan, ketika azan memanggil harus segera mendatangi masjid untuk salat berjamaah.

Untuk menghargai pengunjung yang heterogen, Masjid Jogokariyan tidak memampang tulisan "Kawasan Berjilbab" di area masjid. Menurut takmir, hal ini dilakukan untuk menjaga kenyamanan para tamu. Takmir berpendapat, prinsip dakwah itu "mengajak", sehingga tamu yang tidak berjilbab dapat merasakan atmosfer dakwah di Masjid Jogokariyan. Mengingat lokasi masjid berdampingan dengan daerah wisata, pemandangan yang biasa ada turis asing sekedar singgah atau berfoto melihat aktivitas Masjid Jogokariyan.

Untuk meningkatkan daya tarik bagi jamaah, takmir menghadirkan imam dari pondok pesantran yang memiliki hafalan dan bacaan tartil. Sehingga imam masjid tidak didominasi sesepuh masjid atau sesepuh Kampung Jogokariyan. Selain itu kajian keislaman yang dihadirkan memiliki tema beragam, sesuai segmen masing-masing usia, dari remaja hingga keluarga. Untuk kegiatan keagamaan dan sosial lainnya, takmir juga sering menghadirkan narasumber lokal dan nasional sesuai kompetensi.

Takmir Masjid Jogokariyan juga pernah mengadakan pagelaran wayang kulit yang dihelat di halaman depan Masjid Jogokariyan, untuk mengenang perjuangan Pangeran Diponegoro (Gambar 5). Hal itu menunjukkan fenomena menyatunya masjid dengan warga sekitar. Masjid juga terus berinovasi agar terus seiiring sejalan dengan perkembangan masyarakat. Takmir terus berupaya berdampingan dengan warga melalui rancangan program-program yang dibutuhkan dan menjawab permasalahan sosial kemasyarakatan. 


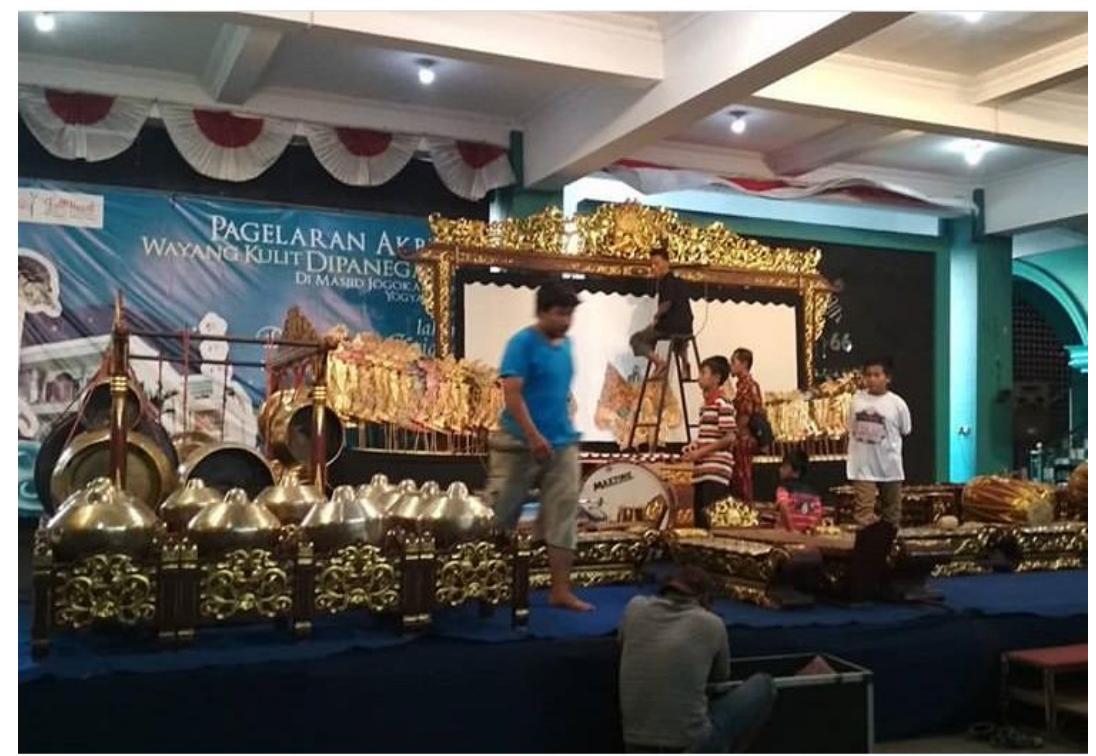

Gambar 5: Pagelaran Akbar Wayang Kulit Diponegoro pada April 2018

(Sumber: Instagram @ masjidjogokariyan)

Upaya memakmurkan Masjid Jogokariyan berhasil dengan adanya komunikasi antarpribadi, yaitu jenis komunikasi yang frekuensi terjadinya cukup tinggi dalam kehidupan sehari-hari. Upaya-upaya yang dilakukan takmir Masjid Jogokariyan ditinjau dari strategi komunikasi antarpribadi dengan membangun komunikasi dua arah antara takmir dan jamaah. Takmir mengambil langkah pendekatan secara personal dan informal melalui kegiatan-kegiatan yang melibatkan masyarakat setempat. Hal ini berdampak pada umpan balik yang positif, seperti terlihat pada kekompakan jamaah. Komunikasi interpersonal takmir Masjid Jogokariyan bersifat dinamis secara timbal balik dan berkelanjutan. Efektifitas komunikasi interpersonal tidak hanya ditentukan oleh pesan tetapi juga hubungan antarpribadi. Hal ini merupakan aktivitas yang dibangun secara berkelanjutan, ada ikatan emosional yang terjalin antara takmir masjid dan jamaah Masjid Jogokariyan.

\section{Simpulan}

Tatanan kehidupan sosial masyarakat dapat dilihat dari eksistensi masjid. Pola komunikasi yang terbentuk mampu membentuk interaksi, meredam gejolak, mengurangi kesenjangan, dan akhirnya dapat menciptakan kemanan dan stabilitas. Salah satu ciri yang menjadikan suatu masjid memiliki tingkat kemakmuran adalah terlihat dari partisipasi aktif warga melakukan salat jamaah. Partisipasi warga melakukan salat berjamaah didorong peran penting takmir. Tercermin dari upaya para takmir melakukan pendekatan kepada warga setempat melalui strategi komunikasi antar pribadi yang tersusun rapi. Selain itu takmir aktif melaksanakan salat berjamaah di masjid. Takmir memiliki prinsip "mensalatkan orang hidup". Masjid Jogokariyan menjadi tempat terbaik untuk berinteraksi, berdiskusi, apalagi mengaji. Masjid selalu 
penuh saat pelaksanaan salat lima waktu dan memiliki jadwal kunjungan studi banding dari beberapa takmir masjid di seluruh Indonesia. Masjid Jogokariyan juga menjadi Masjid Besar Percontohan di Daerah Istimewa Yogyakarta.

\section{Referensi}

Adil, M. A. M., Mohd-Sanusi, Z., Jaafar, N. A., Khalid, M. M., \& Aziz, A. A. (2013). Financial management practices of mosques in Malaysia. GJAT, 3(1), 23-29.

Zaki, A. (2007). Pentadbiran Masjid Secara Profesional. In Abdul Hamid Othman (Ed.), Islam Hadhari: Kekuatan masjid dalam menjana masyarakat gemilang (pp. 2649). Putrajaya: Yayasan Islam Hadhari. Ghani, A. M. A. (2013, May 27). Manfaat waktu terluang.

Arifah, S.A. \& Zulfa, I. (2018). Peran Takmir Dalam Meningkatkan Kemakmuran Masjid (Studi Kasus Di Masjid Al-Huda Citrodiwangsan Lumajang). Dakwatuna Jurnal Dakwah dan Komunikasi Islam, 4 (2). DOI: https://doi.org/10.36835/dakwatuna.v4i2.447

Cangara, H. (2014) Pengantar Ilmu Komunikasi. Jakarta: PT RajaGrafindo Persada.

Creswell, J. (2007) Qualitative inquiry and research design: Choosing among five approaches. 2nd ed. California: Sage Publication.

Ibda, H., \& Saifuddin, K. (2019). Strategi Lembaga Takmir Masjid Nahdlatul Ulama (LTM NU) Temanggung Dalam Mencegah Radikalisme Agama. el-Buhuth: Borneo Journal of Islamic Studies, 1(2). DOI: https://doi.org/10.21093/elbuhuth.v1i2.1604

Instagram: @masjidjogokariyan

Jaafar, A., Habidin, N. F., Hussin, M. M., Zakaria, Z., \& Hamid, A. A. (2013). A proposed model for strategic management (SM) and mosque performance (MP) in mosque management. International Journal of Management, Information Technology and Engineering, 1(3), 29-36.

Liliweri, A. (2011) Komunikasi Serba Ada Serba Makna. Jakarta: Kencana Prenada Media Group.

Mokhtar, S. (2003). Status Imam di Malaysia. In S. Norrodzoh \& Y. Yusmini (Eds.), Membangun Institusi Masjid. Petaling Jaya: Selangor: Jabatan Dakwah dan Pembangunan Insan, APIUM.

Mohamad, W.A.A. (2008). Pendekatan Baru dalam Pengimarahan Masjid. Paper presented at the Multaqa Imam-Imam Masjid Seluruh Negara 15 April 2008 at Masjid Wilayah Persekutuan Kuala Lumpur.

MUIS (2005). Annual report 2005. Singapore: Majlis Ugama Islam Singapura.

Rogers, M. (1975) "Patterns of Leadership in Rural Malay Community," Asian Survey, 15(5), pp. 407-421.

Saniei, M., \& Delavar, A. (2012). Communicational role of mosques architecture. Asian Social Science, 8(3), 137.

Sapri, M., Kaka, M., \& Alias, B. (2010). Performance Management in Service Business: The Facilities Management Function. In Khosrowshahi, F. (ed.) 21st Annual ARCOM Conference. London: SOAS, University of London, pp. 431-40. 
Sapri, M., Muin, Z., \& Sipan, I. (2016) Key Drivers of an Effective Facilities Management Practice for Malaysia State Mosque. In MATEC Web of Conferences 66, p. 0082.

Saputra, A., \& Kusuma, B.M.A. (2017). Revitalisasi Masjid Dalam Dialektika Pelayanan Umat dan Kawasan Perekonomian Rakyat. Al-Idarah: Jurnal Manajemen dan Administrasi Islam, Vol. 1, No. 1, Januari-Juni. DOI: http://dx.doi.org/10.22373/al-idarah.v1i1.1522

Satori, D. \& Komariah, A. (2009) Metodologi Penelitian Kualitatif. Bandung: Alfabeta. Sendjaja, S.D. (1994). Teori Komunikasi. Jakarta: Universitas Terbuka

Sinambela, L. (2010) Reformasi Pelayanan Publik; Teori, Kebijakan, dan Implementasi. Jakarta: Bumi Aksara.

Susanto, D. (2015). Penguatan Manajemen Masjid Darussalam di Wilayah RW IV Kelurahan Banjardowo Kecamatan Genuk Kota Semarang. DIMAS. Jurnal Pemikiran Agama Untuk Pemberdayaan. Volume 15, Nomor 1, Oktober. ISSN :1411-9188(p); 2502-9428 (e).

Utama, I. G. B. R., \& Mahadewi, N. M. E. (2018). Metodologi penelitian pariwisata dan perhotelan. Yogyakarta: Andi Offset.

Azhar, A. W. (2008). Financial Management of Mosques in Kota Setar District: Issues and Challenges (Doctoral dissertation, Universiti Utara Malaysia).

Wall \& Callister, R. R. (1999). Malaysian Community Mediation. The Journal of Conflict Resolution, 43(3): 343-365.

Wells, B., and Spinks, N. (1999). Communicating with the community. Career Development International, Vol. 4(2), pp. 108-116

Yin, R.K (1996). Studi Kasus: Desain dan Metode. Jakarta: Raja Grafindo Persada.

Yosepin, P. \& Husin, B. (2018). Revitalisasi Masjid melalui Kepedulian Sosial Lembaga Takmir Masjid Nahdlatul 'Ulama (LTM NU) terhadap Komunitas Pengemudi. Academic Journal for Homiletic Studies. 12 (1): 121-140. DOI: 10.15575/idajhs.v12i.1939 